\title{
Contribution of General Principles of International Law in Progressive Development of Transboundary Aquifers
}

Atul Alexander \& Anushna Mishra*

DOI: 10.21827/GroJIL.8.2.183-199

\section{Keywords:}

TRANSBOUNDARY AQUIFERS; RESOURCES; STATES; ISRAEL-PALESTINE; INDIA-PAKISTAN

\begin{abstract}
Man's ruthless exploitation of natural resources means that we are housed in a resourcedeprived world. The tug of war for meager resources has led to many conflicts between States that we witness today. At the heart of the whole debate on resource crunch is the issue of shared natural resources between States. International law has formulated several legal instruments to govern the shared transboundary resources, laws on transboundary aquifers being one. The objective of this paper is to unlock the general principles of international law that regulate the transboundary aquifers. In this regard, the paper has been apportioned into three sections. The first section sets the tone by detailing the provisions of the 2008 Draft Articles on the Transboundary Aquifers dealing with general principles. The second segment of the paper lays down the cardinal principles regulating transboundary aquifers, which range from sustainable development to the principle of good faith. The final portion delves into the Israel-Palestine dispute and the India-Pakistan Indus Waters Treaty in the context of transboundary aquifers.
\end{abstract}

\section{Introduction}

Water is an indispensable resource for human survival. In recent times, the demand for water has increased significantly. Most countries have found it difficult to accept a mutual agreement governing water resources. ${ }^{1}$ The impact of globalisation and the subsequent integration of communication, travel, and so on have also influenced the sharing of water resources. ${ }^{2}$

Groundwater makes up 97 percent of total consumable water. ${ }^{3}$ Before World War II, groundwater was a strictly local commodity. However, the spread of vertical turbine pumps paved the way for several disputes, at the heart of which was the Israel-Palestine conflict over shared water resources, especially in relation to transboundary water resources. ${ }^{4}$

* Mr. Atul Alexander is Assistant Professor (Law) at West Bengal National University of Juridical Sciences Kolkata and Ms. Anushna Mishra is $4^{\text {th }}$ Year candidate at West Bengal National University of Juridical Sciences.

1 'Transboundary Waters' (United Nations, 23 October 2014).

$<$ https://www.un.org/waterforlifedecade/transboundary_waters.shtml> accessed 10 May 2020.

2 Karen L O'Brien and Robin M Leichenko, 'Climate Change, Globalization And Water Scarcity' <https://www.zaragoza.es/contenidos/medioambiente/cajaAzul/17S6-P2-OBrienACC.pdf> accessed 13 May 2020.

3 'Groundwater' (Water Encyclopedia) <http://www.waterencyclopedia.com/Ge-Hy/Groundwater.html> accessed 15 May 2020.

4 'Israeli-Palestinian Conflict' (Council on Foreign Relations, 2020) <https://www.cfr.org/global-conflicttracker/conflict/israeli-palestinian-conflict> accessed 31 May 2020.

This work is licensed under the Creative Commons Attribution-NonCommercial-NoDerivatives 4.0 International License. To view a copy of this license, visit http://creativecommons.org/licenses/by-nc-nd/4.0/. 
Transboundary aquifers are networks of rock formations beneath the ground that contain water straddled between more than two countries. ${ }^{5}$ Estimates suggest that there are more than 270 transboundary aquifers worldwide. ${ }^{6}$ Transboundary aquifers constitute a critical element of the global water resource system. However, unlike transboundary rivers, transboundary aquifers have neither been sufficiently recognised by international agreements nor through customary practices. Understanding the various nuances of this becomes crucial, as almost $96 \%$ of the planet's freshwater is found in underground aquifers that mostly straddle across national boundaries. ${ }^{7}$ This requires a multi-pronged approach as it encompasses disciplines like politics, engineering, hydrology, economics, and international law. ${ }^{8}$

While various binding and non-binding laws are available for governing transboundary aquifers, there is an absence of a comprehensive legal instrument for groundwater resource governance. ${ }^{9}$ Due to the significance of water as a pivotal resource, any source of water may be the starting point of a dispute, both on the national and international planes. ${ }^{10}$ Bearing these points in mind, international law (hereinafter also referred to as IL) has carved out several conventions for the sharing of water resources between States. This includes the 1992 Helsinki Convention $^{11}$ concerning the protection and use of transboundary watercourses and international lakes and the 1997 Convention on the Law of the Non-Navigational Uses of International Watercourses (hereinafter referred to as the Watercourse Convention) ${ }^{12}$ along with scores of regional and bilateral treaties on the sharing and utilisation of water resources. ${ }^{13}$

However, most of the abovementioned conventions deal with surface water. Moreover, the laws pertaining to aquifers are not covered under these conventions. In this regard, the role of the International Law Association needs to be underscored. The International Law Association was founded in Brussels in 1873. Its objectives, under its Constitution, are to study, clarify and develop international law, both public and private, and to further international understanding and respect for international law. The Association adopted the Seoul Rules on the Law of International Groundwater Resources ${ }^{14}$ which defined an international aquifer as an 'international drainage basin'. Following the Seoul Rules, the

5 ILC, 'Draft Articles on the Law of Transboundary Aquifers with Commentaries' (2008) UN Doc (A/63/10) (DALTA).

6 Alfonso Rivera, 'Transboundary Aquifers Along The Canada-USA Border: Science, Policy And Social Issues' (2015) 4 Journal of Hydrology: Regional Studies 623, 624.

7 UNESCO, 'Internationally Shared (Transboundary) Aquifer Resources Management Their Significance And Sustainable Management' (November, 2001) SC-2001/WS/40.

8 'Towards the Concerted Management of Transboundary Aquifer Systems: A Methodological Guide' (UNESCO, 5 January 2011) <http://www.unesco.org/new/en/media-services/singleview/news/towards_the_concerted_management_of_transboundary_aquifer_sy/> accessed 17 May 2020.

9 CB Bourne, 'International Groundwater Law. By Ludwik A. Teclaff and Albert E. Utton. London, Rome, New York: Oceana Publications, Inc., 1981. Pp. Xiv, 490. \$50.' (1982) 76 American Journal of International Law 692.

10 Convention on the Protection and Use of Transboundary Watercourses and International Lakes (adopted 17 March 1992, entry into force 6 October 1996) 1936 UNTS 269.

11 ibid.

12 Convention on the Law of the Non-navigational Uses of International Watercourses (adopted 21 May 1997, entry into force 17 August 2014) 2999 UNTS 869.

13 Molly Espey and Basman Towfique, 'International Bilateral Water Treaty Formation' (2004) 40 Water Resources Research 5, 7.

14 Committee on International Water Resources, 'The Seoul Rules on International Groundwaters' in International Law Association Report of the Sixty-Second Conference (Seoul 1986) (International Law Association, Seoul 1986) 251. 
Association's Water Resource Law Committee produced a detailed summary of all customary international law pertaining to water resources, including the Berlin Rules.

Chapter VIII of the Berlin Rules discusses aquifers in detail. ${ }^{15}$ The significance of the Berlin Rules was that it highlighted the need for an integrated approach to aquifer management and outlined the precautionary principle, as well as principles of sustainability and no significant harm, most of which were subsequently codified under the Draft Articles on the Laws of Transboundary Aquifers, 2008 (hereinafter referred to as DALTA) ${ }^{16}$ However, it was not until 2008 that a comprehensive codification of the laws of transboundary aquifers took place. The International Law Commission (hereinafter also referred to as the ILC) acting under the aegis of the United Nations General Assembly (hereinafter also referred to as UNGA) came up with DALTA to tackle the disputes relating to aquifers between straddled States. DALTA continued to be the grundnorm in the sphere of transboundary aquifers, notwithstanding the emergence of customary law and the existing bilateral arrangements. ${ }^{17}$

The post-2008 period witnessed rapid growth in the principles of international law; for instance, the Sustainable Development Goals, which emphasised the sustainable management of water and sanitation for all. ${ }^{18}$ More often than not, the issue of transboundary aquifers is seen as a peripheral issue in the broader context of political disputes, as evident in the conflict pertaining to the Israel-Palestine territorial aquifers. Moreover, the importance of transboundary aquifers cannot be over-emphasised; most of the landlocked European States rely entirely on aquifers. ${ }^{19}$ This paper is a minor attempt to deliberate constructively on the entire gambit of the principles on transboundary aquifers, acknowledging the fact that the existence of IL is not sufficient to deal with the complications on the subjects.

Further, the principles of transboundary aquifers have tremendous potential to compel States to adhere to and respect the international conventions. The purpose of this work is to focus on these fundamental principles and unravel how these principles have contributed to the progressive development of the law on transboundary aquifers. According to the Water Resource Research Center, 'transboundary aquifers are a source of groundwater that defy political boundary'.$^{20}$ Due to the indistinct boundaries associated especially with groundwater aquifers, several challenges have surfaced amongst which include: a) access to transboundary aquifer data, $b$ ) boundary intersection, $c$ ) the binding nature of the principles of transboundary harm and d) the difficulty of persuading States to comply with the principle of transboundary aquifers. The advent of transboundary aquifers in the backdrop of customary international law has not been well explored; the international law rhetoric operates at the level of rules, whereas the acceptance of customary international law is especially relevant in the case of the participation of a few States in the decision-making process. The process of custom formation

15 Water Resources Committee, 'Berlin Rules on Water Resources' (International Law Association, Berlin 2004).

16 Joseph W. Dellapenna, 'The Customary Law Applicable To Internationally Shared Groundwater' (2011) 36 Water International 584, 589.

17 ibid 591.

18 United Nations University Institute for Water, Environment and Health, UN Office of Sustainable Development and Stockholm Environment Institute, 'Water For Sustainability: Framing Water Within The Post-2015 Development Agenda.' (2013) <https://i.unu.edu/media/ourworld.unu.eduen/article/8495/Catalyzing-Water.pdf $>$ accessed 20 May 2020.

19 Tomasz Nałecz, Transboundary Aquifers In The Eastern Borders Of The European Union (Springer 2012), 1732.

20 'Transboundary Aquifers: Water Wars or Cooperative Conservation?' (The Arizona Board of Regents, 2011) <https://wrrc.arizona.edu/awr/sp11/transboundaryaquifer> accessed 23 May 2020. 
in the realm of water law has accelerated in the past decade because of the myriad of claims made by States, which then perhaps turned into law.

For example, widespread industrialisation prompted the diversion of water from its natural setting by upper riparian States. The vogue was that the upper riparian States claimed blanket sovereignty, ${ }^{21}$ regardless of its impact on the other riparian States. The downstream States started demanding that the right of the upper riparian State be limited, and voiced a claim that upper riparian States should not do things that reduce water quality. The claims and counterclaims which resulted between the upper riparian and lower riparian States resulted in the unfolding of the customary principle of 'equitable utilisation'.

It is to be noted that major principles relating to transboundary aquifers thrived because of the divergent views adopted by the States, yet for that same reason, the elevation of the principles in water law as customary law has traditionally stalled. However, the modern constructions of these principles after the 1990s have meant that it is highly possible for these principles i.e. the no significant harm rule, sustainable development, equitable utilisation, exchange of information and prior informed consent, to find an active place in the discourse on transboundary aquifers as customary principles. ${ }^{22}$

Another visible sign of this trend is the unwinding of the 'strict sovereignty doctrine' giving way to the restricted notion of sovereignty ${ }^{23}$ through the negotiation process and international cooperation. The proliferation of States has undoubtedly meant that international cooperation stands at the heart of the sharing of water resources. The principle of international cooperation ${ }^{24}$ will be detailed in the upcoming sections of this paper. Hence, there needs to be a delicate balance between treaty and customary law in order to get a comprehensive picture of the lex lata. Most of the treaties on shared water resources have a common denominator, i.e. assuring 'equal share' between the States. For instance, The Treaty of Peace, Friendship, and Arbitration between the Dominican Republic and Haiti signed in $1929^{25}$ assured 'just and equitable use'. The challenge for international academia is to broaden the relevant principles and its customary character, which will ensure respect and enforcement of these principles. The opinio juris on transboundary groundwater aquifers is currently too narrow to establish any form of customary practice with the exception of the Donauversinkung Case. ${ }^{26}$

The Donauversinkung dispute concerned the upper course of the Danube River, which is characterised by a particular geographical phenomenon: at several places in the former territories of Baden and Württemberg the water sinks into the limestone ground and flows in subterranean passages into the River Aach, a tributary of the Rhine River in Baden. Württemberg, supported by Prussia, claimed that Baden should take measures to stop the

21 Stephen C McCaffrey, 'The Harmon Doctrine One Hundred Years Later: Buried, Not Praised' (1996) 36 Natural Resources Journal 965, 980.

22 DALTA (n 5) art 7.

23 Nadia S Castillo, 'Differentiating between Sovereignty over Exclusive and Shared Resources in the Light of Future Discussions on the Law of Transboundary Aquifers: Sovereignty Over Exclusive and Shared Resources' (2015) 24 Review of European, Comparative \& International Environmental Law 4, 5.

24 Dante A Caponera, 'Patterns of Cooperation in International Water Law: Principles and Institutions' in Albert E Utton and Ludwik A Teclaff (eds), Transboundary Resources Law (Westview Press 1987) 569.

25 Milagros Ricourt, The Dominican Racial Imaginary: Surveying the Landscape of Race and Nation in Hispaniola (Rutgers University Press 2016) 31; Dante A Caponera, 'Patterns of Cooperation in International Water Law: Principles and Institutions' (1985) 25 Natural Resources Journal 563.

26 Matthias Herdegen, 'Donauversinkung Case' in Rudolf Bernhardt (ed), Encyclopedia of Public International Law (10th edn, North Holland Publishing Company 1987) 137-8. 
increased sinking of water caused by a barrage and that it should remove sediments in the bed of the river. Württemberg had closed natural cracks and pores in the bed of the river and had diverted water for the use of a power station. Baden, in turn, asked for an injunction requiring Württemberg to restore the original conditions..$^{27}$ It was held in the said case that, the law applicable to surface water applies to groundwater.

There are nearly thirty major principles pertaining to groundwater resource management; however, this paper delimits to the major principles codified under DALTA, which have undeniably attained the status of customary international law. ${ }^{28}$

\section{Overview of the Adoption of the Draft Articles}

The DALTA has contributed significantly to the field of governing transboundary aquifers. The ILC at its 2008 session forwarded the DALTA to the General Assembly. ${ }^{29}$ The initial work by the ILC in formulating the principles on the management of transboundary waters was to complement its previous work on the law of the non-navigational uses of water resources ${ }^{30}$ The draft articles are categorised into four primary parts which include General Principles, Protection, Preservation and Management, and Miscellaneous Provisions. ${ }^{31}$ Certain provisions of the relevant articles are a reproduction of the corresponding provisions of the Convention on the Law of the Navigational Uses of International Watercourses. The draft articles relevant to the paper are discussed as follows. ${ }^{32}$

Article 3 is the first of the seven articles included in part II of DALTA; it deals with the concepts of the sovereignty of aquifer States over the portions of the aquifer present in its territory. ${ }^{33}$ Article 4 elucidates the principle of equitable and reasonable utilisation. ${ }^{34}$ Subsequently, the draft elaborates on how this principle is applicable in the context of aquifers. A non-exhaustive list of factors that are considered while ensuring the equitable and reasonable utilisation of a transboundary aquifer is laid down in Article $5 \cdot{ }^{35}$ Another important principle is the 'obligation not to cause significant harm', which is enshrined in Article 6 of DALTA. A pivotal aspect of Article 6 is that it puts the responsibility of no significant harm not only on the States sharing the transboundary aquifers, but also on the States 'in whose territory a discharge zone is located' ${ }^{36}$

Article 7 of DALTA focuses on the 'general obligation to cooperate' and puts forth how the States that share water should have mechanisms in place to ensure the same. ${ }^{37}$ The States sharing aquifers are required to engage in the regular exchange of data and information

ibid.

28 Gabriel Eckstein and Francesco Sindico, 'The Law of Transboundary Aquifers: Many Ways of Going Forward, but Only One Way of Standing Still' (2014) 23 Review of European, Comparative \& International Environmental Law 32, 41.

29 DALTA (n 5); UNGA ‘Report on International Law Commission' UN Doc A/63/10 (2008).

30 Convention on the Law of the Non-navigational Uses of International Watercourses (n 12).

31 ibid art 1.

32 Stephen C McCaffrey, 'The International Law Commission Adopts Draft Articles on International Watercourses' (1995) 89 American Journal of International Law 395, 398.

33 DALTA (n 5) art 3.

34 ibid art 4.

35 ibid art 5.

36 ibid art 6.

37 ibid art 7. 
according to Article 8 of DALTA. ${ }^{38}$ Article 9 focuses on the aspect of 'Bilateral and Regional Agreements and Arrangements', which is a modified reproduction of a part of Article 3 of the UNWC. ${ }^{39}$ Article 10 focuses on the 'Protection and Preservation of Ecosystems' ${ }^{40}$ Article 11 of DALTA deals with recharge and discharge zones. These zones are highly important as an aquifer is replenished or recharged through the surface land; it also includes surface areas from where the aquifer emerges into another watercourse like a lake, stream or sea ${ }^{41}$ It is essential to preserve and protect these recharge zones to avoid any contamination of the aquifers. This article mandates both aquifer and non-aquifer States to work together in ensuring the protection of the aquifers and by extension, the ecosystem. Article 13 provides for the 'monitoring of a critical case of groundwater', which implies that there is a need for monitoring of groundwater by the States that share the aquifers jointly. ${ }^{42}$

\section{Sovereignty over Exclusive and Shared Resources}

'Transboundary aquifers' are defined in DALTA as 'a permeable water-bearing geological formation underlain by a less permeable layer and the water contained in the saturated zone of the formation'. ${ }^{43}$ Furthermore, DALTA has incorporated a novel principle, i.e., sovereignty. The recognition of sovereignty over transboundary aquifers is controversial because the principle of Permanent Sovereignty over the Natural Resource (hereinafter referred to as PSNR) is applied to the shared aquifer by reference to the UNGA Resolution 1803 (XVII) as reflected in the preamble of DALTA. ${ }^{44}$ During the drafting of DALTA, an intensive debate took place on the incorporation of the phrase 'PSNR' wherein it was agreed to place the term in the preamble. This was a paradox, considering the point that sovereignty and the sharing of aquifers are conceptually contradictory, and the challenge is to reconcile these opposites.

Although DALTA refers to sovereignty as a sacrosanct principle, it is limited by the other principles embedded in DALTA. These principles include equitable use, no harm, information exchange, and cooperation. ${ }^{45}$ The exercise of sovereignty over shared water natural resources requires revisiting in terms of finding alternate models, such as drastically vitiating sovereignty from the paradigm of the transboundary aquifer. Otherwise, the recognition of sovereignty over shared natural resources would certainly dissuade international cooperation, as States would perceive that any effort to cooperate would dilute their sovereignty. Therefore, the right approach would be to maintain limited sovereignty. ${ }^{46}$

The other rules, i.e. the no-harm rule and the theory of limited territorial sovereignty, have done very little to protect the environment as a shared natural resource. Unlike the principle of sovereignty, the principle of no-harm is grounded on due diligence and is based on specific circumstances ${ }^{47}$ The basis of all these principles rests on the protection of territorial

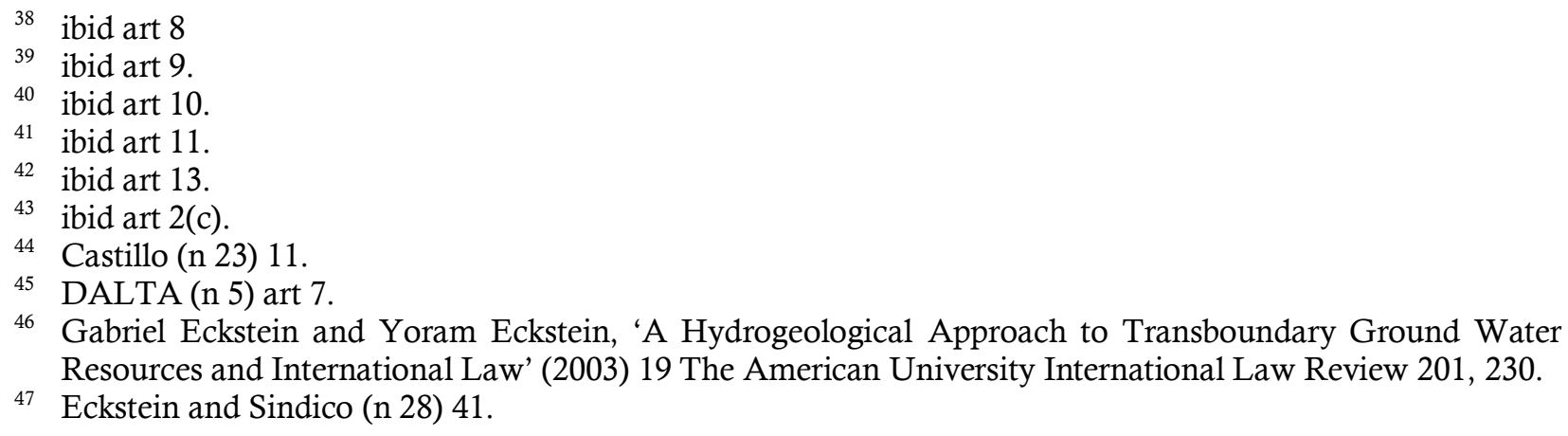

46 Gabriel Eckstein and Yoram Eckstein, 'A Hydrogeological Approach to Transboundary Ground Water Resources and International Law' (2003) 19 The American University International Law Review 201, 230.

47 Eckstein and Sindico (n 28) 41. 
sovereignty. ${ }^{48}$ The no-harm principle attempts to provide a balanced approach to territorial sovereignty rather than an eco-centric angle to preserve the environment and the sovereignty principle is not sustainable because of the cyclical nature of water movement. ${ }^{49}$

The language of DALTA is more inclined towards protecting the interests of sovereign States by allowing States to exercise their sovereign right (PSNR) over a shared resource. It is interesting to compare DALTA with other international law instruments, namely the Charter of Economic Rights and Duties of States (CERDS), ${ }^{50}$ The Draft Principles of Conduct in the Field of the Environment for the Guidance of States in the Conservation and Harmonious Utilization of Natural Resources Shared by Two or More States (the UNEP Draft Principles) ${ }^{51}$ and the Watercourse Convention. ${ }^{52}$ The common denominator in all these instruments is the protection of interests over a shared resource. Despite the reluctance of the States to incorporate the term 'shared', the special rapporteur Chusei Yamada ${ }^{53}$ was persuaded to add the term 'shared' because of the acceptance of the principle of 'equitable utilisation'.

The principle of PSNR is exercised over the exclusive jurisdiction of the State; this was affirmed in the UNGA Resolution 3171 (XXVIII). ${ }^{54}$ However, the shared resource is distributed over the international boundaries of two or more States; the resource could be groundwater, oil, natural gas etc. Because of the nature of the resource, it is difficult to partition the same. The utilisation of resources in one portion of the territory significantly affects the other part. For instance, the water abstraction in part of the territory will alter the flow of water in other parts of the territory. ${ }^{55}$ Therefore, the States must cooperate and manage the resources jointly. The shift from exclusive sovereignty to shared sovereignty was codified for the first time in the Stockholm Declaration in $1972 .{ }^{56}$ Further, the contribution of the UNGA resolutions addressed the need for prior consultation and harmonious exploitation of resources. The UNEP Draft Principles, in paragraph three outlines the elements of shared resources as a) equitable utilisation, b) exchange of information and consultation c) no harm rule and d) transboundary cooperation. All these rules are equally applicable in the case of transboundary aquifers. ${ }^{57}$ This paper attempts to decipher each of these concepts in detail. The fact remains, the post-globalisation world is heading from sovereignty to shared or limited sovereignty for resources, forming a single unit and distributed amongst two or more States. The principle of PSNR took off in the backdrop of decolonalisation in order to strengthen the

48 Nico Schrijver, Sovereignty Over Natural Resources: Balancing Rights And Duties (Cambridge University Press 1997) 218-237.

49 Gabriela M Kutting, Conventions, Treaties And Other Responses To Global Issues - Volume I (EOLSS Publications 2009) 354 .

50 UNGA Res 3281 (XXIX) (6 November 1974).

51 Governing Council of UNEP, 'Principles of Conduct in the Field of the Environment for the Guidance of States in the Conservation and Harmonious Utilization of Natural Resources Shared by two or More States' (19 May 1978).

52 Convention on the Law of the Non-navigational Uses of International Watercourses (n 12).

53 'Analytical Guide to the Work of the International Law Commission' (United Nations, 29 May 2019) $<$ https://legal.un.org/ilc/guide/8_6.shtml> accessed 20 May 2020.

54 Castillo (n 23) 9; UNGA Res 3171 (XXVIII) (17 December 1973) UN Doc A/RES/3171.

55 Igor S Zektser and Lorne G Everett, Groundwater Resources Of The World And Their Use (UNESCO 2004) 19.

56 'Report of the United Nations Conference on the Human Environment' (Stockholm 5 June-16 June 1972) (November 1973) UN Doc A/CONF.48/14/REV.1.

57 Governing Council of UNEP (n 51). 
colonised States' exercise of self-determination and protect the economic autonomy of the colonised States. ${ }^{58}$

The resolutions of the UNGA 523, 626 (VII), 1515(XV) augmented the sovereign right and recognised PSNR as an integral facet of the 'right to self-determination'. DALTA included these principles in the preamble and rightfully omitted the phrase 'shared natural resource'. The developing States articulated the inclusion of PSNR as a safety valve against the emergence of neo-colonialism in terms of tackling specific scenarios concerning States and foreign investors, enforcement of investment agreements, etc. The dawn of environmental consciousness witnessed a palpable drift towards shared resources and congestion between PSNR, and shared resources reached new heights. ${ }^{59}$

The 1970s is regarded as the age of environmental enlightenment in the sphere of ecological governance ${ }^{60}$ as principles like the state responsibility for transboundary harm were codified. International cooperation became the buzzword, and UNGA resolutions further strengthened this stance through resolutions 3129(XXVIII) and 2995 (XXVII). The UNEP Draft Principles Principle $3^{61}$ also acknowledges the existence of different regimes for exclusive and shared resources. The UNEP Draft Principles are not binding; but most of the principles have attained customary law status. DALTA including the principle of PSNR to protect territorial sovereignty certainly diverges from the recent developments concerning shared resources.

\section{Transboundary Water Cooperation and Sustainable Development Goals}

Transboundary water cooperation has become an integral part in ensuring sustainable development. ${ }^{62}$ The Brundtland Report defines sustainable development as the 'development that meets the needs of the present without compromising the ability of future generations to meet their own needs' ${ }^{63}$ The two primary concepts of sustainable development include, first, the essential needs of the world's poor, which gets overriding priority. Second, it recognises the limitations of the environment and requires states to take this into account when meeting the needs of the present.

The groundwater that is found in aquifer systems forms the safest source of drinking water, thereby becoming the world's most extracted raw material. ${ }^{64}$ It accounts for a substantial amount of everyday freshwater used for irrigation purposes, cooking, drinking, and hygienic purposes..$^{65}$ The pressure on groundwater usage has been increasing exponentially. Still, the statutory and legal attention given for its safeguard has not been taken up as a priority

58 Eckstein and Eckstein (n 46) 10.

59 ibid 10.

60 Adil Najam, Mihaela Papa and Nadaa Taiyab, Global Environmental Governance: A Reform Agenda (International Institute for Sustainable Development 2006) 44.

61 Governing Council of UNEP (n 51) principle 3.

62 Francesco Sindico, 'Transboundary Water Cooperation and the Sustainable Development Goals' (United Nations Educational, Scientific and Cultural Organisation 2016) 1-48.

63 UNGA 'Report of the World Commission on Environment and Development: Our Common Future' (4 August 1987) UN Doc A/42/427, 41.

64 Zektser and Everett (n 55) 97.

65 'WWDR1: Water for People, Water for Life' (UNESCO, 2013) < http://www.unesco.org/new/en/naturalsciences/environment/water/wwap/wwdr/wwdr1-2003/> accessed 20 May 2020. 
either in the international policy framework or among various legislatures. ${ }^{66}$ Aquifers can range from small localised aquifers to a regional aquifer system such as the Iullemeden Aquifer System or Nubian Sandstone Aquifer System; ${ }^{67}$ even then, the development of rules and regulations on them has been very nascent. The mismanagement of water as a natural resource also becomes an integral factor in drawing considerable attention.

UNESCO's International Hydrological Program (IHP) that studied these systems thoroughly observed that with the water scarcity crisis in the coming years, the presence of transboundary aquifers will be a source of conflict. ${ }^{68}$ This program holds abundant importance as it has successfully established cooperation concerning sharing aquifer systems between countries. ${ }^{69}$ If these are not managed efficiently with adequate safeguards, States can suffer adversities like groundwater pollution, among others. The consequences of the same will be experienced not only by the States which use the source but also by the neighbouring States. Therefore, it becomes essential to keep in place sustainable development goals for the judicious use of this precious natural resource.

The importance of sustainable development can be understood not only in its 'logical necessity' but also in the general recognition it has gained worldwide. ${ }^{70}$ Another issue that was addressed by Judge Christopher Gregory Weeramantry in the Gabcikovo-Nagymaros case was the appropriateness of using the rules of inter partes litigation to determine erga omnes obligations. ${ }^{71}$ Such inter partes issue might need reconsideration in the times to come as that could lead to catastrophic environmental danger to stakeholders other than the immediate parties in the dispute. Here, he addressed an ongoing debate between sustainable development versus the right to develop. This form of inadequacy in technical judicial rules primarily in the decisions on scientific matters has been a matter of criticism by various scholars. ${ }^{72}$ The consequences of a particular environmental change are not restricted to only the parties but have a larger impact. International environmental law should account for the global concerns which impact the world holistically rather than merely confining it to the rights and obligations of the parties. ${ }^{73}$

Transboundary aquifers traverse through international borders, and their management becomes complicated as multiple nations which have different institutional arrangements and

66 Albert E Utton, 'The Development of International Groundwater Law' (1982) 22 Nat Resources Journal 95, 104.

67 Elena Quadri, 'The Nubian Sandstone Aquifer System - A case of cooperation in the making' (2017) International Water Resources Association, 1-10; The Nubian Sandstone Aquifer System (NSAS) is the largest known fossil aquifer in the world, home to one of the largest reserves of non-recharging groundwater. It lies in the eastern part of the Sahara consisting of two large basins: the Nubian Sandstone Aquifer (NSA), which is the more ancient and the larger of the two, and straddles the political borders of four North-eastern African States, i.e., Chad, Egypt, Libya and Sudan; and the more recent Post-Nubian Aquifer (PNA), which underlies only Egypt and Libya.

68 Alice Aureli and Raya M Stephan, 'Transboundary Aquifers: International Law And Politics?' (2008) 102 Proceedings of the ASIL Annual Meeting 356, 356-359.

69 ibid 356.

70 ibid 402.

71 See the Separate Opinion of Judge Weeramantry, Gabčíkovo-Nagymaros Project (Hungary v Slovakia) (Judgement) [1997] ICJ Rep 7, 117-118.

72 ibid 118.

73 ibid 118. 
policy frameworks are involved..$^{74}$ In the last few decades, the rampant growth of population, increasing reliance on groundwater for various purposes, have stressed the use of transboundary aquifer systems. ${ }^{75}$ The preamble of DALTA enshrines the principle of sustainable development. It emphasises the optimal use of these resources for the present and future generations. ${ }^{76}$

The implementation of the Sustainable Development Goals in a nuanced manner becomes vital as the management of transboundary water resources includes issues of sharing, maldistribution, misuse, and over-exploitation. ${ }^{77}$

\section{Equitable and Reasonable Utilisation or the No Significant Harm Principle}

Groundwater being the most extracted resource, it is vital to ensure an equitable and reasonable utilisation. The Watercourse Convention mandates watercourse States to utilise any course of international water equitably and reasonably. ${ }^{78}$ Article 6 of the Watercourse Convention carries a non-exhaustive list of factors which may be equitable and reasonable. ${ }^{79}$ It includes factors like the geographical, hydrological and other natural character concerning factors, the dependency on the watercourse by the population of a State, socio-economic factors influencing the use of water, conservation, protection and development of water, and the availability of alternatives of a comparable nature. ${ }^{80}$ This concept is primarily utilitarian and aims to ensure maximum utility of the available resources by sharing the water resource in the territories where the aquifers are found. However, this concept has been questioned, and other alternate concepts have also been a matter of discussion. Certain objections were raised by the ILC and the sixth committee of UNGA to determine whether the concept of 'equitable and reasonable utilisation' can be used to manage transboundary aquifers. ${ }^{81}$

The 'no significant harm' principle enshrined in Article 7 of the Watercourse Convention states that watercourse States must 'take all appropriate measures to prevent the causing of any significant harm to other watercourse States' ${ }^{82}$ However, the definition of 'significant harm' or the threshold to be attained is unclear. Further, since surface water and groundwater sources have differing characteristics, applying the same standards to both is problematic. It is vague whether the harm must be tangible and have an effect on the usage of water by another State or whether environmental terms can be used to define harm to the

74 Werner Aeschbach-Hertig and Tom Gleeson, 'Regional Strategies for the Accelerating Global Problem of Groundwater Depletion' (2012) 5 Nature Geoscience 853, 858.

75 Yoshihide Wada and Lena Heinrich, 'Assessment of Transboundary Aquifers of the World-Vulnerability Arising from Human Water Use' (2013) 8 Environmental Research Letters 2, 4.

76 See also DALTA (n 5) art 23.

77 Nurit Kliot, Deborah Shmueli and Uri Shamir, 'Institutions for Management of Transboundary Water Resources: Their Nature, Characteristics and Shortcomings' (2001) 3 Water Policy 229, 230.

78 Convention on the Law of the Non-navigational Uses of International Watercourses (n 12) art 5.

79 ibid art 6.

80 ibid art 6.

81 UNGA 'Second Report on Shared Natural Resources: Transboundary Groundwater' (2004) UN Doc A/CN.4/539, 40.

82 Convention on the Law of the Non-navigational Uses of International Watercourses (n 12) art 7. 
aquifer ${ }^{83}$ Considering the difficulties and expenses associated with aquifer remediation, more stringent standards must be in place to account for the threshold of the 'significant harm' principle when any harm occurs to an aquifer. ${ }^{84}$

\section{Israel-Palestine Transboundary Water Management}

The rationale behind choosing the Israel-Palestine dispute pertaining to transboundary aquifers over other bilateral disputes is because of its massive international involvement in terms of players like the United Nations. The United Nations' fixation over this dispute is evident from the fact that the United Nations Security Council (UNSC) has passed an unprecedented number of 79 resolutions on Arab-Israel conflict as per 2010 data. ${ }^{85}$

The transboundary water conflict between Israel and Palestine is presently more than 20 years in the making. ${ }^{86}$ The impact of water scarcity is nowhere felt more than in the region of the Middle East. Since World War II, the crisis in the Middle East on resources has been brought to the fore. Groundwater is considered to be one of the hardest fought resources. The groundwater resource in the Middle East is mostly shared between two or more States. The two Oslo Agreements regulate the law governing the sharing of water resources in the region ${ }^{87}$ and were entered between Israel and Palestine in September 1994 and 1995, respectively. The Israel-Palestine conflict over the water resource is acute as the recharge zone for the Juda aquifer is distributed over Samaria, Hebron, and Judea, which are located in the disputed Israel-occupied West Bank part excluding eastern Jerusalem. At this juncture, more than hydrology and geography, it is pivotal to decipher the agreements linking Israel and Palestine the transboundary conflict. ${ }^{88}$

By the first Oslo Agreement in 1994, it was agreed by Israel to transfer control over the Palestinian water supply in Gaza to Palestine..$^{89}$ Further, it was agreed that Israel would transfer 5 million cubic metres per year (hereinafter referred to as ' $\mathrm{MCM} / \mathrm{Y}$ ') to Gaza through a pipeline. The second Oslo Agreement was signed in 1995. This concurred with the view that Palestine's needs in the future would be $70-80 \mathrm{MCM} / \mathrm{Y}$, and it was further decided to develop new water resources for seawater desalination in the region of Judea and Samaria. The mechanism to implement the Agreement was to take place through a Joint Water Commission (JWC) with the joint supervision of both of the States. The Commission consists of four committees, i.e., hydrological, engineering, sewage, and pricing committees, which look into the aspects of drilling to solve issues pertaining to payment. Since the establishment of the JWC, the dispute persists on various fronts, with the frontrunner being the fact that the water

83 Gabriel E Eckstein 'Protecting A Hidden Treasure: The U.N International Law Commission and the International Law of Transboundary Ground Water Resources' (2005) 5 Sustainable Development Law \& Policy 5, 8.

84 Second Report on Shared Natural Resources: Transboundary Groundwater (n 82) 21.

85 Jeremy Hammond, 'Israeli Violations Of U.N. Security Council Resolutions' (Foreign Policy Journal, 2021) <https://www.foreignpolicyjournal.com/2010/01/27/rogue-state-israeli-violations-of-u-n-security-councilresolutions/> accessed 17 June 2020.

86 Alon Tal, 'International Water Law and Implications for Cooperative Israeli-Palestinian Transboundary Water Management' in Clive Lipchin, Eric Pallant, Danielle Saranga and Alysson Amster (eds), Integrated Water Resources Management and Security in the Middle East (Springer 2007) 213-236.

87 'Shared Water Resources in Palestine' (Fanack, 5 June 2015) <https://water.fanack.com/palestine/sharedwater-resources/> accessed 21 May 2020.

88 ibid.

89 ibid. 
resource of Palestine is controlled by Israel along with endogenous aquifers. ${ }^{90}$ The important principle of equitable utilisation governing transboundary aquifers has been flouted by Israel through over-exploitation and pollution in the West Bank through the incessant dumping of industrial and agro-chemical wastes.

Further, when discussing the Israel-Palestine aquifer, it is pertinent to delve into the application of the principles of transboundary aquifers in the said context. The first doctrine is the Harmon doctrine, ${ }^{91}$ i.e. the absolute sovereignty of every nation within its territory, while the opposite to the Harmon doctrine is the historical rights doctrine ${ }^{92}$ which is that if the State enjoys the water flowed into an area under her control, then she is entitled to receive the water. The second Oslo Agreement provided the JWC wide authority to operate the aquifer. Palestine was always in favour of the principle of 'riparian use ${ }^{93}$ and demanded Israel to return all the water from the mountain aquifer. In contrast, Israel claimed the right over the aquifer based on historical use. The subsequent negotiation made very little headway, and the sustainable solution to the water crisis in Palestine requires consensus across the board. Amjad Aliewi points towards a four-pronged approach to the water crisis, which includes that:

a) Palestinian water rights should be resolved according to international legal principles, which will guarantee sufficient quantities and grant sovereignty to Palestinians to utilise and control their water resources.

b) Palestinian water rights should extend to their indigenous and shared groundwater aquifers as well as surface water, including the Jordan River.

c) Final agreements will have to ensure the removal of any obstacles in Palestinian lands that limit Palestinian rights (e.g., access to wells currently controlled by Israel inside the West Bank, the separation wall constraints imposed by Israeli settlements, etc.).

d) Bilateral and multilateral cooperation remain key elements in any final status negotiations over Palestinian water rights.

The second Oslo Agreement has been defined as an interim agreement while many portions of the agreement remain vague. The accusations and counter-accusations are ubiquitous. Israel accuses Palestine of digging wells, while Palestine accuses Israel of overexploitation, the breach from both sides means that the principles enshrined under Article 40 of the second Oslo Agreement (Annex III) ${ }^{94}$ are blatantly violated. As the second Oslo Agreement envisages, deepening negotiation could go a long way in resolving the outstanding disputes.

90 Haim Gvirtzman, 'The Israeli-Palestinian Water Conflict: An Israeli Perspective' (2012) Mideast Security and Policy Studies No. 40, 23

$<$ https://www.pseau.org/outils/ouvrages/besa_the_israeli_palestinian_water_conflict_an_israeli_perspective_ 2012.pdf accessed> accessed 23 May 2020.

91 Philip A Baumgarten, 'Israel's Transboundary Water Disputes' (2009) Pace Law School Publications, 2 $<$ https://digitalcommons.pace.edu/lawstudents/2> accessed 23 May 2020.

92 Gvirtzman (n 91) 19.

93 Juliette Niehuss, 'The Legal Implications of the Israeli-Palestinian Water Crisis' (2005) 5 Sustainable Development Law \& Policy 13, 15.

94 UNSC 'Israeli-Palestinian Interim Agreement on the West Bank and the Gaza Strip' (28 September 1995) UN Doc S/1997/357. 


\section{India-Pakistan Indus River Water Plain Aquifers: Need For A Comprehensive Legal Framework}

The Indian subcontinent encompasses 23 percent of the world population within the limited land area of about 3 percent, thereby becoming the most densely populated region of the world. ${ }^{95}$ The importance of transboundary aquifers is thus immense as various issues pertaining to food and water security are dependent on them. In India, the transboundary nature of these water resources has led to several 'acrimonious issues' over the usage of water. ${ }^{96}$ Taking into consideration various nuances of groundwater management, it becomes essential to understand the continuous and extensive management of transboundary aquifers. It is crucial to implement various laws concerning the governing of transboundary aquifers. One of such aquifers which has recently been in the limelight is the India-Pakistan Indus River Water Plain Aquifers. ${ }^{97}$

The Indus River water flows from the Tibetan Plateau and flows through India and Pakistan and its source supports an estimated 215 million people. ${ }^{98}$ The Indus water is regulated by the Indus Water Treaty. One of the salient features in the Treaty is international cooperation and the creation of the Permanent Indus Commission (PIC) to undertake periodic inspections.

However, due to the relatively recent focus on the subject of groundwater, the Indus Water Treaty does not deal with groundwater but primarily focuses on surface water. This is problematic, as India and Pakistan also share the Indus Water Plain Aquifer, an unconfined/semi-confined groundwater source located beneath the Indus Basin that is currently experiencing several problems associated with over-exploitation. ${ }^{99}$

The rampant exploitation of groundwater in the region has meant that the water table is on the decline. One study conducted by NASA revealed that the Indus Basin was the second-most overstressed aquifer in the world. ${ }^{100}$ Scholars have argued in favour of incorporating provisions on groundwater aquifers in the Indus Water Treaty, which would go a long way in addressing the issue of groundwater depletion in the region. ${ }^{101}$ Moreover, the aquifers could be governed by the principle of equitable utilisation and principle of no harm, as these principles have been invoked with regard to surface water. The legitimacy of using these principles is also derived from the fact that they have been elevated to the status of customary international law. The initiation of dialogue on an agreement on groundwater aquifers requires political commitment and compromise, and there are very few bilateral

95 Abhijit Mukherjee et. al, 'Groundwater Systems Of The Indian Sub-Continent' (2015) 4 Journal of Hydrology: Regional Studies 1, 1.

96 ibid 1.

97 Hassan Abbas and Asghar Hussain, 'To Save Pakistan, Look under Its Rivers' (The Third Pole, 27 September 2019) <https://www.thethirdpole.net/2019/09/27/pakistans-riverine-aquifers-may-save-its-future/> accessed 21 June 2020.

98 Fazila Nabeel, 'How India and Pakistan Are Competing over the Mighty Indus River' (DownToEarth, 21 February 2019) <https://www.downtoearth.org.in/news/water/how-india-and-pakistan-are-competingover-the-mighty-indus-river-63321> accessed 21 June 2020.

99 Sahana Rao, 'Governance of Water Resources Shared by India and Pakistan Under the Indus Waters Treaty: Successful Elements And Room for Improvement' (2017) 25 New York University Environmental Law Journal 108, 129.

100 'Indus Basin Is World's Second Most "overstressed" Aquifier' (Hindustan Times, 18 June 2015) $<$ https://www.hindustantimes.com/india/indus-basin-is-world-s-second-most-overstressed-aquifier/storykzOWAy5q0R26rgBiksJ1hI.html> accessed 21 June 2020.

${ }^{101}$ Rao (n 99) 130. 
precedents to rely upon for either State. ${ }^{102}$ The ideal principle that may be incorporated in the bilateral treaty could be the precautionary principle. Considering the fact that the data on the quantification is impossible to ascertain, the precautionary principle would be difficult to infuse into the existing Indus Treaty because of the absence of the principle in the said Treaty. One possible way to overcome the situation is to incorporate the phrase 'groundwater' in the provisions of the Indus Treaty alongside surface water and demarcate the allowable use.

\section{Significance of Good Faith Obligation in Complying with the Principles of Transboundary Aquifers}

The popular and contemporary definition of good faith stems from the landmark Nuclear Tests judgment. ${ }^{103}$ The International Court of Justice (ICJ) in the said case observed:

One of the basic principles governing the creation and performance of legal obligations, whatever their source, is the principle of good faith. Trust and confidence are inherent in international cooperation, in particular in an age when this cooperation in many fields is becoming increasingly essential. Just as the very rule of pacta sunt sevanda in the law of treaties is based on good faith, so also is the binding character of an international obligation assumed by unilateral declaration. ${ }^{104}$

The principle of good faith also finds resonance in Article 26 of the Vienna Convention on Law of Treaties (VCLT) ${ }^{105}$. The jurisprudence of Article 26 of VCLT is vast and hence requires a cogent interpretation, which forms a pillar of international law.

In the sphere of transboundary aquifers, the principle of good faith is cardinal, as treaties and resolutions on transboundary aquifers in the context of shared resources are mainly soft law mechanisms. ${ }^{106}$ The negotiation between the competing rights and interests is evident from the cases involving aquifer States, where the compromise between States happens at the level of the source State and affected State. However, in certain instances, the negotiations are caught in the tussle of power politics wherein one State holds the upper hand, as seen in the case study of Israel-Palestine, the Oslo Agreements and subsequent interim agreements signed against the backdrop of a volatile political environment. ${ }^{107}$ However, States have an obligation to negotiate in good faith, avoid coercion and establish a 'sanctity of obligations'. A good faith obligation finds a mention in Article 7 of DALTA ${ }^{108}$ as a general obligation to cooperate. The good faith obligation encompasses both substantive and

102 Pilar C Villar, 'Transboundary Aquifers Archives' (International Water Law Project Blog, 16 November 2020) $<$ https://www.internationalwaterlaw.org/blog/category/transboundary-aqufers/> accessed 19 June 2020.

${ }_{103}$ Nuclear Tests (Australia v France) (Judgement) [1974] ICJ Rep 253.

104 ibid [46].

${ }^{105}$ Vienna Convention on the Law of Treaties (adopted 23 May 1969, entry into force 27 January 1980).1155 UNTS 331 (VLCT), art 26.

106 Cameron J Hutchison, 'Coming in from the Shadow of the Law: The Use of Law By States to Negotiate International Environmental Disputes in Good Faith' (2006) 43 Canadian Yearbook of International Law $101,101$.

107 'Israeli-Palestinian Conflict' (Council on Foreign Relations, 2020) <https://www.cfr.org/global-conflicttracker/conflict/israeli-palestinian-conflict> accessed 31 May 2020.

${ }^{108}$ DALTA (n 5) art 7. 
procedural limbs; the latter of which is reflected in Article 8, ${ }^{109}$ i.e. the regular exchange of data and information. The provision states that:

Pursuant to draft Article 7, aquifer States shall, on a regular basis, exchange readily available data and information on the condition of their transboundary aquifers or aquifer systems, in particular of a geological, hydrogeological, hydrological, meteorological and ecological nature and related to the hydrochemistry of the aquifers or aquifer systems, as well as related forecasts.

One of the bones of contention in the Israel-Palestine transboundary aquifer conflict is the available data being skewed. The difficulty of accessing the relevant data in the field of transboundary aquifers is because of the diverse data that exist with regard to aquifers. For instance, the Franco-Swiss Genevese Aquifer Management Commission ${ }^{110}$ had difficulties harmonising the data as a result of the two sides interpreting according to their own standards.

One of the germane concepts that requires more clarity is the substantive content of good faith. Presently, good faith merely rests on the doctrine of 'reasonableness' ${ }^{111}$ That said, in practice, the legal indeterminacy on the substantive content will not be a problem as States will have the incentive to settle or arrive at a political solution. ${ }^{12}$ It can be deciphered that, when the rules are narrower, negotiations take place in good faith, essentially implying that good faith fills the gap left unaddressed by the treaty framework. The application of good faith requires accommodation of the rights and interests of the two or more States, and in the domain of shared resources, good faith plays a crucial role in facilitating consensus amongst States.

As stated, good faith covers legal indeterminacy and offers clarity to the uncertain realm of transboundary resources, an uncertainty which stems from scientific ambiguity (cause, effect, and risk) and complexity of social choices, in terms of cost and benefits analysis. The essence of soft law is to protect the legitimate interest and thus ward-off self-interest in interpretation. ${ }^{113}$ In the Lake Lanoux arbitration, ${ }^{114}$ the rule of good faith meant that the upstream State is under an obligation to consider various interests. The reconciliation of the riparian State was recognised as an important factor for the equitable utilisation of the shared watercourse.

Primarily, good faith encompasses reconciliation of the legitimate interests of the States. In Gabcikovo-Nagymaros case, a landmark case of the ICJ involving the negotiating of legitimate interests, ${ }^{115}$ the two interests that the ICJ had to evaluate were the social and economic needs of the watercourse State and protection of drinking water supply. The ICJ's interpretation in an integrated manner reconciled the no significant harm principle with

\footnotetext{
109 ibid art 8.

110 'Franco-Swiss Genevese Aquifer' (International Waters $<$ http://www.internationalwatersgovernance.com/franco-swiss-genevese-aquifer.html $>$ accessed 1 June 2020.

111 Robert Kolb, 'Principles as Sources of International Law (With Special Reference to Good Faith)' (2006) 53 Netherlands International Law Review 1, 16.

112 DALTA (n 5) art 9.

113 ibid art 16.

${ }^{114}$ Lake Lanoux Arbitration (Francev Spain) (1957) Arbitral Tribunal 12 RIAA 281.

115 Gabčíkovo-Nagymaros Project (Hungary v Slovakia) (Judgement) [1997] ICJ Rep 7.
} 
equitable utilisation and favoured harm in certain exceptional circumstances, as the risk of the harm was a mere possibility. Of course, it was criticised in the sense of sustainable development. It is widely held that good faith norms, when recognised, will enable attainment of environmental protection goals. Apart from the shared transboundary resources, good faith norms are also reflected in the areas of laws regulating trade, straddling fish stock management, etc. ${ }^{116}$ As mentioned in DALTA, information on the aquifers is crucial to realise the equitable sharing of water resources. The good faith doctrine in the context of aquifers finds affinity in terms of exchange of data and information. As reflected in Article 8 of DALTA, which uses the language of 'best efforts', States are required to make use of the best means at their disposal to share data as the sharing of data is especially productive when the aggrieved States are the developing economies. The data to be provided includes, inter alia, geological, meteorological and hydrogeological information. The sharing of data usually takes place jointly and includes all available research and analysis of aquifers. Through this joint management, as with the Nubian Sandstone System or the EU Water Framework Directive, ${ }^{117}$ the purpose of collective management is to ensure transparency and accountability.

\section{Conclusion}

This paper has revealed the significance of the general principles of international law in resolving disputes relating to transboundary aquifers. The challenge, however, is to urge States to comply with these general principles in good faith. Since contemporary disputes on transboundary aquifers are resolved by resorting to regional or bilateral treaties, these treaties ought to incorporate the general principles in substance and spirit, especially in the backdrop of international politics. Also, there is a requirement for balancing treaty and customary law to ensure the smooth enforcement of these principles, as most of these principles have attained the status of customary international law. Hence, State compliance needs to be rephrased from the commonly held soft law conception. The onset of globalisation had set the stage for principles like sustainable development, the no harm principle and limited sovereignty in the context of the transboundary aquifer to thrive. Nevertheless, the reticence of States to enhance the scope and content of some of these principles has meant that these principles have not transformed beyond soft laws.

Through this doctrinal study, the authors have identified certain grey spots which require an amicable solution; firstly, the authors contend that rather than being confined to rights and obligations, international law should apply the general principles with consistency in order to render equitable solutions to the volatile crises over hard-fought shared resources. Secondly, the need to reconcile these principles ought to be emphasised, as some of these principles contradict the rights and interests of different States. This would ensure a legal solution to the political struggle. Thirdly, in the course of this research, the authors were able to identify the gap in terms of data on the transboundary aquifer where the developed economies have access to the most sophisticated and accurate data and technologies, hence hold an upper hand in the bargaining process. The authors believe that enhancing better international cooperation and transfer of technology can go a long way in bridging the gap between developed and developing economies and thus ensuring equitable resource distribution.

116 DALTA (n 5) art 7.

${ }^{117}$ Council Directive 2000/60/EC of 23 October 2000 establishing a framework for Community action in the field of water policy [2000] OJ L327/1 (Water Framework Directive). 
